\title{
TOWARDS A FRAMEWORK FOR DISASTER RISK REDUCTION IN INDONESIA'S URBAN TOURISM INDUSTRY BASED ON SPATIAL INFORMATION
}

\author{
Agustan AGUSTAN ${ }^{1}$, Devi Roza Krisnandhi KAUSAR ${ }^{2}$
}

DOI: 10.21163/GT_2019. 141.16

\begin{abstract}
:
Tourism is among the highest growing sectors in Indonesia, with international tourists' arrival of 14.4 million in 2018 and tourism being the top five export earners for the country. Despite the positive growth, tourism is also a highly volatile industry, easily affected by safety, security and health issues and natural disasters. Being one of the world's most vulnerable countries to hazards, an approach to tourism disaster management is needed to help the affected tourists, tourism industry and communities whose livelihoods depend on tourism to cope with the disasters and its social amplifications. This study which focuses on urban tourism, aims to identify possible tourism disasters in urban areas and develop an approach for disaster management planning which considers the risks in urban tourism, the disaster process and how the interactions of information, organizations and systems can be facilitated and mediated by spatial information in the event and aftermath of disasters. The study uses literature based research methodology in which it uses other study as the data. A framework of urban tourism crises and disaster management that is developed from this study will be discussed further with stakeholders through action research in future study.
\end{abstract}

Key-words: Disaster Risk Reduction, Framework, Spatial Planning, Tourism.

\section{INTRODUCTION}

Tourism is among the top five export earners in Indonesia along with the oil and gas sector, coals, palm oil and rubber. International tourists' arrival to Indonesia reached 14.4 million in 2018. Tourism is an important sector as it attracts people from other parts of the world to visit Indonesia's natural landscapes and experience its unique culture. Despite the positive growth, tourism is also a precarious industry, which is easily affected by safety and security issues such as wars and terrorism, health issues and natural disasters. Indonesia is one of the world's most vulnerable countries to natural hazards, namely earthquake, tsunami, flood, landslides, volcanic eruption, extreme weather condition, extreme sea waves, drought and forest fire. Many of Indonesia's tourism destinations are actually located in areas with higher risks of natural disasters, such as Borobudur Temple and the highland of Kaliurang that lie in proximity to one of the world's most active volcanoes, Merapi Volcano; the still active Bromo Volcano in East Java and Tangkuban Perahu Volcano in West Java; as well as Pangandaran beach - once devastated by tsunami.

Richardson as cited in (Faulkner, 2001) argued that the world we live in has become more complex thus making us more prone to crisis or disaster, especially when the incidence of disasters seems to be increasing or have more devastating effects. Complexity means that the natural and human systems are more and more intertwined; hence to isolate cause and effect relationships in each disaster has become more complicated (Faulkner,

\footnotetext{
1 Agency for the Assessment and Application of Technology (BPPT) - Center of Technology for Regional Resources Development (PTPSW), Jakarta, Indonesia, agustan@bppt.go.id;

2 Universitas Pancasila - Faculty of Tourism, Jakarta, Indonesia, devikausar@univpancasila.ac.id
} 
2001). This is even more so in urban area, which are often complex, connected, diffuse and diverse (McHale et al., 2015). Ruda (2016) considered Geographical Information Systems (GIS) which it helps to plan manage and control tourism safety development.

Currently, research on disaster phenomena and the impacts of such events on the tourism industry as well as how they cope with these impacts are still very limited (Faulkner, 2001; Mistilis \& Sheldon, 2005; Ritchie, 2004). Research on tourism and natural disasters in Indonesia has arisen after the incident of tsunami in Pangandaran in 2006, Yogyakarta earthquake also in 2006 and Merapi Volcano eruption in 2010 (Akbar \& Sujali, 2012; Hardiani, 2014; Permana, 2015; Agustan et al., 2016).

However, several frameworks have been developed within this topic (Faulkner, 2001; Ritchie, 2004; Mistilis \& Sheldon, 2005: Hystad \& Keller, 2008). Faulkner (2001), Ritchie (2004), and Hystad \& Keller (2008) develop the framework based on stages on disaster though with different focuses. Faulkner (2001) on response in each stage, Ritchie (2004) on the ability of organizations to formulate strategic plan with regards to disaster anticipation and response, and Hystad \& Keller (2008) on tourism stakeholders' roles in each stage. Mistilis \& Sheldon (2005), on the other hand, focuses on knowledge management for crises and disasters in tourism.

Other studies on tourism disasters have different emphases, such as Rittichainuwat (2012) and Rittichainuwat et al. (2018) on the perceptions of tourists and tourism industry towards disaster risks, Huan et al. (2004) on the need to study psychological and behavioral consequences of fear and risk in order to mitigate no-escape natural disaster, Cioccio \& Michael (2007) on how communities prepared for and recovered from disaster, and Tsai \& Chen (2011) on the establishment of rapid natural disaster risk assessment model for the tourism industry.

This study which focuses on urban tourism, aims to identify possible tourism disasters in urban areas and develop an approach for disaster management planning which considers the risks in urban tourism, the disaster process and how the interactions of information, organizations and systems can be facilitated and mediated by geospatial information in the event and aftermath of disasters. Among the existing frameworks and previous research, spatial information has not been given appropriate attention.

This study which focuses on urban tourism, aims to identify possible tourism disasters in urban areas and develop an approach for disaster management planning which considers the risks in urban tourism, the disaster process and how the interactions of information, organizations and systems can be facilitated and mediated by geospatial information in the event and aftermath of disasters. Among the existing frameworks and previous research, spatial information has not been given appropriate attention.

In the case of Indonesia, there are three legal bases behind why geospatial data and information should be included in tourism activity planning, in particular in tourism disaster management planning, i.e. Law No. 24 of 2007 on Disaster Management, Law No. 26 of 2007 on Spatial Planning and Law No. 4 of 2011 on Geospatial Information. Explicitly, Article 21 on Law No. 24 of 2007 instructs that disaster prone maps should be developed, defined and informed at the district or municipality level.

This paper will take the form of a conceptual paper proposing new relationships among existing models. Existing models that the authors try to integrate is the Faulkner (2001) model and Mistilis \& Sheldon (2005) model. The authors see the potential of integrating these models, as the former is strong in conceptualizing phases and strategies in disaster process, whereas the latter identifies knowledge management framework for crises and disasters in tourism. Bridging three concepts, i.e. phases in disaster process, knowledge 
management and urban tourism, the integrated model put forward the use of spatial data to assist in realizing each phase strategy into maps.

The study uses literature based research methodology in which the literature review is a methodology in its own right or as the main contribution for the study (Kitchenham, 2004).

\section{CONCEPTUAL FRAMEWORK}

Urban areas are the environments for multiple activities with various economic, political and socio-cultural motives (McAdams, 2008). These multiple activities are also influenced by the presence of governmental and non-governmental bodies at various scales. Nevertheless, (McAdams, 2008) argued that the social, political and economic activities are carried out within the physical and built environment of urban areas with opportunities and constraints such as growing population, density and employment, therefore urban planning must confront and challenge to effectively guide urban development. Other study (Godschalk, 2003) stated that cities or urban areas are complex and inter-reliant systems, which are at risk to threats from both natural hazards and terrorism. Features that characterized cities, such as architectural structures, population concentrations, places of assembly and interconnected infrastructure systems also put them at high risk to natural as well as man-made disaster and terrorist attacks (Godschalk, 2003).

According to the UN, the world's urban population is expected to grow by $61 \%$ by 2030, the number of people living in cities will rise to 5000000000 by 2030. In addition, cities have become one of the preferred tourist destinations (Page \& Hall, 2003) generating a new form of tourism that can be defined as urban tourism. UNWTO refers to urban tourism as trips taken by travelers to cities or places of high population density. The duration of these trips is usually short (one $d$ to three $d$ ) hence the short-breaks markets are the main targets of urban tourism marketing (WTO, 2012).

Urban areas offer social, cultural, physical and aesthetic features, which often serve also as urban tourism attractions. However, these urban tourism attractions features are shared with residents and most of them are actually developed for non-tourism purposes (Hayllar et al., 2008). Previous study (Ashworth, 2012) mentioned that urban tourism may cover cultural, heritage, meetings and events, gastronomic, night-life, shopping and health tourism which are carried out in urban areas. Tourism areas located in a broader urban context trigger complex interaction between tourists, local residents and the city as the setting for the interactions (Krolikowski \& Brown, 2008).

The characteristics of urban tourism with an array of attractions and multiple usages of facilities and infrastructure, both for residents and visitors, present another challenge in the topic of tourism crises and disaster mitigation and management. Unlike nature-based tourism area, in which natural disaster is the type of disaster that is likely to happen, urban tourism stakeholders-herein urban tourism industry must prepare for different types of crises and disaster, ranging from earthquakes, floods, fire, terrorism, to land subsidence phenomenon that can lead to disaster albeit not immediately.

Tourism disaster management framework (Faulkner, 2001) consists of phases in disaster process, elements of the disaster management responses and principal ingredients of the disaster management strategies. Phases in disaster process according (Faulkner, 2001) include pre-event, prodromal (when a disaster is imminent), emergency, intermediate, long term recovery and resolution. 
Faulkner's tourism disaster management framework was applied in the case study of Katherine Flood in Australia (Faulkner \& Vikulov, 2001), whereas Miller \& Ritchie (2003) applied it to the 2001 Foot and Mouth Outbreak in the UK. Both applications were recorded in research papers, while the practical applications, for instance by destination managers or authorities had yet to be discovered. Ritchie (2004) suggested a strategic and holistic approach to crises and disaster management, whilst stressed that chaos and change are an important part of public and private sector management which should be embraced and considered in modern tourism management. Using Faulkner (2001) model as a starting point, Ritchie (2004) developed a strategic management framework which consists on proactive planning and strategic formulation, strategic implementation that involves responsive organizational structure, and organizational learning and feedback to ensure continual refinement of crisis management strategies. On the other hand, (Mistilis \& Sheldon, 2005) developed knowledge management framework for crises and disasters in tourism. The framework outlines how knowledge is collected, stored, processed and disseminated for preventative planning and action at the time of the disaster and recovery planning. It also stated that knowledge framework should be developed as an integral part of the wider destination disaster plan.

\section{ANTICIPATING CRISES AND DISASTER RISKS IN URBAN TOURISM}

As mentioned before, urban tourism industry must prepare for different types of crises and disaster, ranging from earthquakes, tsunami, floods, fire, terrorism, to land subsidence. In 2010, Yogyakarta as one of the most important tourists' destinations in Indonesia had to deal with the impact of Mount Merapi eruption, which caused $70 \%$ decline in the number of tourists. In the town of Kumamoto, Japan, famous for its heritage site Kumamoto Castle built in 1467, a magnitude of 6.2 earthquake caused damages to the heritage.

Urban tourism in Jakarta has also experienced crises related to security issues, such as the Marriott bombing in 2003 or the bombings and shootings, which happened last year in the business district of Jalan Thamrin. In addition, there are also possible risks associated with the fact that some of the attractions in Jakarta are heritage buildings built centuries ago or monuments built around 40 to 50 year ago. The $132 \mathrm{~m}$ tower of National Monument (Monas), for instance, has limited capacity of 10 persons in its elevator due to the shape of the monument that is narrower as the tower reaches more heights. Management of Monas needs to be aware of the risk of earthquake and fire and prepares evacuation plan that deals with the challenge of evacuating through narrow stairs. It is reported that steep and narrow stairs caused difficulties for people taking the emergency stairs when Monas elevator broke as reported by Kompas Newspaper on May 2014.

Different risks exist in Jakarta Old Town area, which consists of heritage buildings dated back to the Dutch colonial era centuries ago. Land subsidence due to uncontrolled ground water extraction has already affected some buildings in Jakarta Old Town (i.e. Chaussard et al., 2013). In addition, earthquake also poses a threat to these heritage buildings.

\section{URBAN TOURISM CRISES AND DISASTER MANAGEMENT FRAMEWORK}

In an attempt to develop a framework for urban tourism crises and disaster management, this study adopts Faulkner's framework (Faulkner, 2001) with Mistilis and Sheldon's knowledge management framework for crises and disaster in tourism (Mistilis \& 
Sheldon, 2005). A new framework is developed from the two, considering the risks in urban tourism that partly resulted from the characteristics of the urban area that is complex, diffuse, diverse and connected. In this framework, the pre-event and prodromal phase or in short, the pre-crises and disaster phase, is defined as the phase of knowledge retrieval and storage process, in which data, information, policies and regulations should be retrieved and stored and for some to be developed into spatial information if needed. The spatial information can be used in preventative planning (knowledge base 1 or KB 1), the knowledge processing when crises and disaster occur in which Urban Tourism Command Center is activated (KB 2) and during the aftermath (long term recovery and resolution) in which it is useful for mapping recovery areas. With spatial information, it is expected that the interactions of information, organizations and systems can be facilitated and mediated in the pre-event, during and aftermath of disasters.

Ideally, spatial information should encompass various resources for knowledge retrieval and storage that will be useful for different phases of the disaster (Fig. 1). In addition, the inclusion of spatial information related to disaster prone areas, evacuation route maps and safe zone maps will be useful for managing the tourists' sites. Particularly those where the level of vulnerability is high. Vulnerability is strongly associated with population density, hence popular tourism sites has high vulnerability index due to high number of visitors. Spatial information related to vulnerability and risk should always be available at the tourism information center at the municipality level or even better in each site. It can also be disseminated through on site signage and interpretation.

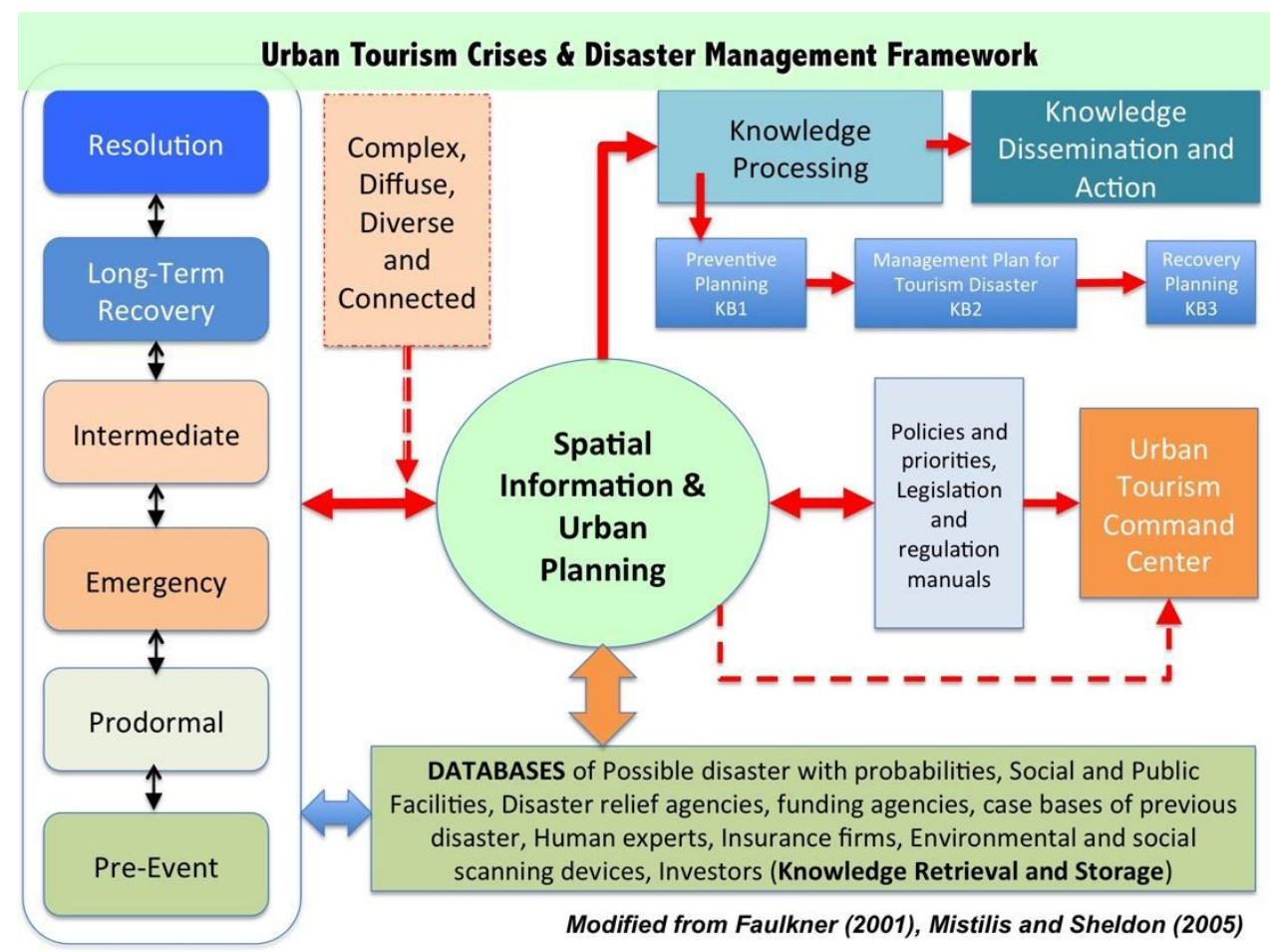

Fig. 1. Urban tourism crises and disaster management framework. 


\section{CONCLUDING REMARK}

This study aims to identify possible tourism disasters in urban areas and develop an approach for disaster management planning which considers the risks in urban tourism, the disaster process and how the interactions of information, organizations and systems can be facilitated and mediated by spatial information in the event and aftermath of disasters. The characteristics of urban tourism with an array of attractions and multiple usages of facilities and infrastructure present challenges for tourism crises and disaster mitigation and management. Possible tourism disasters in urban tourism area that have been identified include earthquakes, tsunami, fire, and how older buildings need to be equipped with evacuation plans that overcome the issue of growing visitor numbers in limited space.

There is also terrorism risk in urban tourism areas which calls for emergency response. In addition, land subsidence phenomenon which affects the preservation of heritage buildings. Adopting Faulkner's framework and Mistilis and Sheldon's knowledge management framework, a new framework is developed from the two, which considers the risks in urban tourism that partly resulted from the urban area characteristics, that is complex, diffuse, diverse and connected. This framework also emphasizes the use of spatial information to facilitate and mediate the interactions of information, organizations and systems in the pre-event, during and aftermath of disasters. The framework proposed from this study still needs further consultations with stakeholders in the form of an action research to ensure its applicability and effectiveness.

\section{REFERENCES}

Agustan, A., Kausar, D., \& Kriswati, E. (2016) Linking interpretations with amenities: Educating visitors in volcanic environments. Tourism, Leisure and Global Change, 3, 1-10.

Akbar, T. \& Sujali (2012) Perceptions and expectations for the development of post-tsunami pangandaran beach tourism. Jurnal Bumi Indonesia, 1 (2), 227-235.

Ashworth, G. (2012) Do we understand urban tourism? Journal of Tourism and Hospitality, 1(4), 1-2.

Chaussard, E., Amelung, F., Abidin, H., \& Hong, S. H. (2013) Sinking cities in Indonesia: ALOS PALSAR detects rapid subsidence due to groundwater and gas extraction. Remote Sensing of Environment, 128, 150-161.

Cioccio, L., \& Michael, E. J. (2007) Hazard or disaster: Tourism management for the inevitable in Northeast Victoria. Tourism Management, 28(1), 1-11.

Faulkner, B. (2001) Towards a framework for tourism disaster management. Tourism Management, 22(2), 135-147.

Faulkner, B. \& Vikulov, S. (2001) Katherine, Washed Out One Day, Back on Track The Next: A Post-Mortem of a Tourism Disaster. Tourism Management, 22 (4), 331-344.

Godschalk, D. R. (2003) Urban Hazard Mitigation: Creating Resilient Cities. Natural Hazards Review, 4 (3), 136-143.

Hardiani, D. (2014) The effect of susceptibility of Mount Merapi disaster to spatial pattern tourism activities: case study of Sleman regency. Thesis, Universitas Gadjah Mada, Yogyakarta

Hayllar, B., Griffin, T. \& Edwards, D. (2008) Urban Tourism Precincts: Engaging with the Field. In Hayllar, B., Griffin, T. \& Edwards, D. (Ed) City Spaces-Tourist Places: Urban Tourism Precincts. Butterworth-Heinemann, Oxford, 3-18.

Huan, T-C, Beaman, J. \& Shelby, L. (2004) No-escape Natural Disaster: Mitigating Impacts on Tourism. Annals of Tourism Research, 31 (2), 255-273.

Hystad, P. \& Keller, P. (2008) Towards a Destination Tourism Disaster Management Framework: Long-tern Lessons from a Forest Fire Disaster. Tourism Management, 29 (1), 151-162. 
Kitchenham, B. (2004) Procedures for performing systematic reviews. Technical Report, Keele, UK, Keele University, 33, 1-26.

Krolikowski, C. \& Brown, G. (2008) The Structure and Form of Urban Tourism Precincts: Setting the Stage for Tourist Performances. In Hayllar, B., Griffin, T. and Edwards, D. (Ed), City SpacesTourist Places: Urban Tourism Precincts. Butterworth-Heinemann, Oxford, 127-149.

McAdams, M. A. (2008) Complexity theory and urban planning. Urban Affairs and Public Policy, Spring-Fall 2008, IX.

McHale, M. R., Pickett, S. T. A., Barbosa, O., Bunn, D. N., Cadenasso, M. L., Childers, D. L., Gartin, M., Hess, G. R., Iwaniec, D. M., McPhearson, T., Peterson, M. N., Poole, A. K., Rivers III, L., Shutters, S. T., \& Zhou, W. (2015) The new global urban realm: complex, connected, diffuse, and diverse social-ecological systems. Sustainability, 7 (5), 5211-5240.

Miller, G. \& Ritchie, B.W. (2003) A farming crisis or a tourism disaster? An analysis of the foot and mouth disease in the UK. Current Issues in Tourism, 6 (2), 150-171.

Mistilis, N. \& Sheldon, P. J. (2005) Knowledge management for tourism crises and disasters. Tourism Review International, 10 (1-2), 39-46.

Page, S. \& Hall, C. M. (2003) Managing Urban Tourism. Prentice Hall, Harlow.

Permana, S. A. (2015) Disaster information system management: case studies of Jogja responsive in managing information on the disaster of the Merapi eruption. Seminar Nasional Universitas PGRI Yogyakarta, 301-310.

Ritchie, B. R. (2004) Chaos, Crises and Disasters: A strategic approach to crisis management in the tourism industry. Tourism Management, 25(6), 669-683.

Rittichainuwat, B. N. (2013) Tourists' and tourism suppliers' perceptions towards crisis management on tsunami. Tourism Management, 34, 112-121.

Rittichainuwat, B. N., Nelson. R. \& Rahmafitria, R. (2018) Applying the perceived probability of risk and bias toward optimism: implications for travel decisions in the face of natural disasters. Tourism Management, 66, 221-232.

Ruda, A. (2016) Exploring tourism possibilities using GIS-based spatial association methods. Geographia Technica, 11 (2), 87-101.

Tsai, C-H. \& Chen, C-W. (2011) The establishment of a rapid natural disaster risk assessment model for the tourism industry. Tourism Management, 32, 158-171.

World Tourism Organization (2012) Global Report on City Tourism. Cities 2012 Project, UNWTO, Madrid. 